\title{
Martin Luther King, Jr., and the Long Social Gospel Movement
}

\author{
Vaneesa Cook
}

On April 4, 1967, as Martin Luther King, Jr., prepared to break his silence on the issue of the Vietnam War at New York City's Riverside Church, he knew many Americans would be bewildered, even outraged. King's public voice, considered radical by some, moderate by many, was well known for positive messages of unity and hope. Now he was announcing his decisive and divisive break with prevailing opinion, the liberal establishment, and any individual or enterprise explicitly or tacitly tied to the "bloody, immoral, obscene slaughter" in Southeast Asia. ${ }^{1}$

Historians have posited several theories in an attempt to explain what many regard as King's radical departure, in the late 1960s, from his earlier, liberal framing of civil rights reform. Rather than view his increasingly critical statements against the Vietnam War and the liberal establishment as evidence of a fundamental change in his thinking, scholars such as Douglas Sturm and Nikhil Pal Singh have braided the continuity of King's thought within frameworks of democratic socialism and the long civil rights movement, respectively. ${ }^{2}$ In his book, Black Is a Country, Singh stated: "King refused to see his antiwar stance... as inconsistent with his earlier views. The [civil rights] movement that he had come to personify was never limited to securing the rights of black people, he said. ${ }^{\prime 3}$ King's lifelong struggle for racial justice in America, in other words, was rife with broader and more radical implications than that of a national campaign for political inclusion. His message was global, and it was revolutionary.

Singh is right to rescue King's image and significance from the safe, sanitized, and largely national narrative of incremental racial progress in the 1950s and 1960s. In the past ten years, he and a handful of historians have produced important, revisionist work which places King within a much more radical tradition than the liberal reformism

Religion and American Culture: A Journal of Interpretation, Vol. 26, Issue 1, pp. 74-100, ISSN: 1052-1151, electronic ISSN: 1533-8568. 2016 by The Center for the Study of Religion and American Culture. All rights reserved. Please direct all requests for permission to photocopy or reproduce article content through the University of California Press's Reprints and Permissions web page, http://www.ucpress.edu/journals.php?p=reprints. DOI: 10.1525/rac.2016.26.1.74. 
one reads about in textbooks. ${ }^{4}$ However, when depicting him exclusively in the context of black radicals during "the long civil rights movement," or the socialist labor movement, scholars have a tendency to downplay the most fundamental component of King's activismhis religion. Calling King a democratic socialist, for example, is not incorrect, but it is incomplete, given that the term fails to recognize fully the religious contours of his radicalism. More so than he referenced the brave black leaders of previous civil rights campaigns, King drew upon the writings and ideas of past and present social gospel thinkers, such as Walter Rauschenbusch and Reinhold Niebuhr. This is not to discount King's legacy in "the long civil rights movement," but to understand better the internal, intellectual, and emotional motives for his participation in campaigns for civil rights and social justice. By analyzing King within the context of "the long social gospel movement" in addition to "the long civil rights movement," we can explain his radical social mission in terms of race and class, but without sidelining the deeply imbedded Christian values at the core of his calling.

Lewis V. Baldwin has covered the complexities of King's relationship to the black church tradition and movement, which, Baldwin argues, represent "the most important sources in the shaping of King's life, thought, vision, and efforts to translate the ethical ideal of the beloved community into practical reality." Baldwin's concern to correct the "narrow, elitist, and racist approach" of scholars who choose to focus primarily on the white theologians that King encountered in college, particularly social gospelers, undoubtedly helps us form a more accurate understanding of the formative influences on King's career and his conception of community. ${ }^{5}$ However, it does not adequately address the fact that King framed his entire religious vision, including his vision of the black church, through a radical conception of the social gospel. His childhood experiences among black preachers in the oppressed American South certainly instilled King with "social concern" early on, but it was his exposure to social gospel thinkers such as Walter Rauschenbusch that provided the "theological basis" and practical, "concrete framework" needed to move him beyond the moderate activism of his father and home church. ${ }^{6}$ For the rest of his life, King kept the social gospel central to his radical thought and practice, while never abandoning his black Baptist roots. ${ }^{7}$ The social gospel, in fact, became for him the transcendent standard by which he judged, through countless jeremiads, the church as a conservative institution and the shortcomings of black religions around the globe. ${ }^{8}$

Notably, a number of recent scholars have identified an intersection between King's radicalism and his religiosity. David L. Chappell, 
in his book A Stone of Hope, argues that civil rights leaders such as King embarked upon radically, and seemingly futile, progressive campaigns in the 1950s and 1960s because of their religious faith. ${ }^{9}$ Throughout Croing Down Jericho Road, Michael K. Honey also acknowledges the significance of the social gospel in shaping King's radical response to the injustices of capitalist labor. ${ }^{10}$ They remind us that King's conscience pivoted on a pillar of faith in the Kingdom of God and the brotherhood of man, something King feared his followers and critics would misunderstand. "Beyond the calling of race or nation or creed is the vocation of sonship and brotherhood," he stated in his antiwar address. ${ }^{11}$ And, for those who questioned the relevance of foreign policy to his role as civil rights leader, King lamented that "such questions mean that the inquirers have not really known me, my commitment or my calling." "They seem to forget that before I was a civil rights leader, I answered a call, and when God speaks, who can but prophesy." ${ }^{13}$ Accordingly, we should remember that King's mission was a religious one, "to preach the gospel," and not just any gospel, but a radical social gospel aimed at changing the world. ${ }^{14}$

The concept of a radical social gospel may be new to many historians, in large part because the social gospel movement is typically remembered as a late nineteenth- to early twentieth-century phenomenon in which liberal, white religious leaders extended their ministry into the streets of urban America, directly applying Christian ethics to social problems such as poverty, industrialization, and education. According to the standard declension narrative, the social gospel movement, while influential during the Progressive Era, lost momentum during and after the horrors of World War I, which severely limited the appeal of religious sentiment and rational progress. ${ }^{15}$ Since then, it has been often relegated to the wastebin of modern history. Scholars such as Christopher Lasch and theologians such as Reinhold Niebuhr criticized liberal Protestantism in general and the social gospel in particular for its romantic, utopian faith in progress and perfectibility which failed to account realistically for the persistence of sin, coercion, and the never-ending struggle for power. ${ }^{16}$ While Ralph Luker demonstrated social gospelers' commitment to racial reform, scholars such as Susan Hill Lindley and Darryl M. Trimiew have cited the narrow racial parameters and top-down paternalism of the early social gospel as irrelevant and perhaps even injurious to subsequent social justice movements. ${ }^{17}$

Other historians of the social gospel, however, have suggested that the movement towards a Kingdom of God based on peace, equality, and cooperation survived well into the late twentieth century and even into today. ${ }^{18}$ As early as 1976, Ronald C. White, Jr., and 
C. Howard Hopkins (amending his earlier work) contended that the social gospel spans the liberal to radical spectrum and continuously "speaks of a social consciousness and mission that is being renewed in every succeeding generation," including King's generation. "The social gospel emerged with renewed vigor in the turbulent sixties as one of the not always recognized roots of the variegated social justice movement," they avowed. ${ }^{19}$

Supporting this notion, theologian Max L. Stackhouse has traced the evolution of what I will call "the long social gospel movement," comprised of at least three subsequent manifestations since its "classic" heyday in the early twentieth century. Stackhouse cites Christian realism (second phase), the civil rights carnpaign of the 1950s and 1960s (third phase), and liberation theology (fourth phase), which prevailed primarily in decolonizing nations throughout Asia, Africa, and Latin America in the wake of World War II, as expressions of the social gospel. ${ }^{20}$ Martin Luther King, Jr., made connections with all four of Max Stackhouse's phases of the tradition. His struggle to develop a practical application of the social gospel in the midtwentieth century accounts for both the continuity and the subtle changes of King's thought throughout his lifetime. Most notably, his effort to reconcile his social gospel values with the continual presence of evil in the world framed his beliefs about violence and war, particularly the white supremacy of the South and, later, U.S. military involvement in Southeast Asia.

While many scholars of King have acknowledged the influence of the social gospel on his thought and activism, ${ }^{21}$ the centrality of social gospel theology in King's intellectual and political development has received insufficient attention, though it is clear that, throughout his adult life, King took an active interest in works by social gospelers. ${ }^{22}$ At Crozer Theological Seminary, he absorbed the writings of Walter Rauschenbusch. Later, he was drawn to the theological arguments of Christian realists, such as Reinhold Niebuhr, who recognized sin and evil as the inherent, fixed, and determinative truths of human nature. While King's embrace of Christian realism prompted him to reevaluate Rauschenbusch's theology, it did not signify a departure from the social gospel. ${ }^{23}$ Instead, King synthesized Christian realism and the classic social gospel to create a new, more radical version of religious activism relevant to the experiences and needs of the racially and economically oppressed. With his strategy of nonviolent direct action and grassroots community building, King retained the core substance of social gospel discourse and praxis, but radicalized it with Niebuhr's insights into the persistence of $\sin$ and power. 
Though he recognized the human failings that corrupted the prevailing social and economic order, King always kept faith in the potential of people to redeem society by choosing love and goodness over hate. Social gospel theology, he felt, provided him with a crucial foundation for proper action. Yet King applied the social gospel as a project of cultural renewal inherent in the revolution of values he believed would herald the Kingdom of God on earth. King understood that religious and social redemption required getting to the roots of the problem within the hearts and minds of individual sinners. "The enemies of those struggling for freedom and democracy," he stated in 1966, "are not man. They are discrimination, dictatorship, greed, hatred and violence, which lie with the heart of man." ${ }^{24}$ He went further in this mission, however, than the moderate moral suasion of classic social gospelers who advocated reform in the early twentieth century. Through a dialectical process of constructive confrontation against injustice and the reconciliation of former enemies around principles of ethical conduct, King hoped to build beloved communities, and thus the Kingdom of God on earth, from the bottom up.

Historians cannot grasp King's comprehensive mission without understanding his devotion to advancing a radical social gospel for the world. Indeed, the changes in King's thinking and language throughout the 1960s represent a refinement, not a total transformation, of his basic social gospel beliefs. It helps explain why we find King talking about labor rights and anti-imperialism as early as 1961. He may have become more outspoken on these issues as national and world events pricked his conscience throughout the turbulent decade of the 1960s, but his reading of the social gospel had always lead him toward a radical vision of social equality. By understanding King's worldview in the context of the long social gospel movement, the continuity of King's thinking and the historical trajectory of his radical religious ethos become more evident.

Early in his adult life, Martin Luther King, Jr., identified social issues as the central component of his religious worldview. As the son of a successful Baptist preacher, King grew up amid economic security and religious traditionalism. Daily living in Georgia, however, soon introduced him to the variety of racial and economic injustices against African Americans. Lynching, legal prejudice, segregation, and unshakable poverty-antitheses of civic and religious principlescreated a climate of "ordinary" violence in the Jim Crow South, yet social injustices were not limited to blacks. King was also struck by the plight of poor whites, who were, he wrote, "exploited just as much as the Negro." ${ }^{.25}$ Such experiences prompted King to question the conventional practice of American democracy and the conservative agenda of 
Christian fundamentalism, both of which tacitly accepted the status quo. Neither conventional democracy nor conservative fundamentalism, he realized, could challenge social injustice and redeem national ideals without a radical reassertion of basic, transposable democratic and Christian values such as love, equality, cooperation, and fellowship. Consequently, King felt the need for a belief system conducive to the social ethics and message of a true Christian democracy.

"Not until I entered Crozer Theological Seminary in 1948," King wrote, "did I begin a serious intellectual quest for a method to eliminate social evil." 26 At Crozer, King absorbed the evangelical liberalism of professors such as George Washington Davis, who taught that the "spirit of all mature religions is social, and sociality does not stifle individuality". but helps to nurture human interdependence, solidarity, and personal dignity. During a course with Davis on the topic of "Great Theologians," King was introduced to the writings of Walter Rauschenbusch, the most famous proponent of classic social gospel theology. King was particularly struck by the powerful insights of Rauschenbusch's 1907 book Christianity and the Social Crisis, which, he wrote, "left an indelible imprint on my thinking by giving me a theological basis for the social concern which had already grown up in me as a result of my early experiences." ${ }^{27}$

Like many Protestant liberals in the early-twentieth century, Rauschenbusch emphasized the social significance of Jesus' message. Jesus, he believed, had intended the ethic of love to permeate all social relations all over the world, thus creating a "brotherhood of man" and the Kingdom of God on earth. By following in the steps of Jesus, humans had powerful agency to direct history toward the Kingdom of God on earth - the progressive, social realization of God's will. Rauschenbusch also placed Jesus within the tradition of Hebrew prophets, who "demanded right moral conduct as the sole test and fruit of religion" and insisted that "social problems are moral problems on a large scale." ${ }^{28}$ Prophets served as public jeremiads exhorting believers to express ideals of, and repentance for, salvation in social terms. In short, the redemptive fate of individuals, nations, and, thus, global humanity was heralded as interdependent and mutually reinforcing. As Rauschenbusch explained, "Every human life brought under control of the new spirit which [Jesus] himself embodied and revealed was an advance of the kingdom of God." Using the basic ethic of love, "Jesus worked on individuals and through individuals, but his real end was not individualistic, but social, and in his method he employed strong social forces. ${ }^{\prime 29}$ To follow in the steps of Christ, Rauschenbusch argued, the Christian church needed to engage with the here and now more than the hereafter. 
In the social gospel, King found a corporate corrective to the passive, conservative, and other-worldly religion of his youth. "It has been my conviction ever since reading Rauschenbusch," King wrote in 1958, "that any religion which professes to be concerned about the souls of men and is not concerned about the social and economic conditions that scar the soul, is a spiritually moribund religion only waiting for the day to be buried. ${ }^{\prime \prime 3}$ In his 1963 collection Strength to Love, King reaffirmed his belief that "the gospel at its best deals with the whole man, not only his soul but also his body, not only his spiritual well-being but also his material well-being." ${ }^{31}$ Indeed, the core themes of social gospel theology, including social justice, human solidarity, the love ethic, and the kingdom ethic, remained salient for the rest of King's life, permeating nearly all of his speeches, sermons, and essays and underscoring his commitment to racial and class equality. "Christians are bound to recognize any passionate concern for social justice," King proclaimed in one of his published sermons. "Such concern is basic in the Christian doctrine of the Fatherhood of God and the brotherhood of man." 32

Calling himself "a profound advocate of the social gospel," King expressed his conviction that human goodness and the power of love could overcome individual and social ills if strenuously applied. ${ }^{33}$ However, his familiarity with the violence and injustice of racism and poverty presented serious challenges to any unequivocal optimism. He doubted the effectiveness of moral suasion alone in convincing white supremacists, for example, of their sins. As King remembered, "The more I observed the tragedies of history and man's shameful inclination to choose the low road, the more I can to see the depths and strength of sin. My reading of the works of Reinhold Niebuhr made me aware of the complexity of human motives and the reality of sin on every level of man's existence." ${ }^{34}$

The theological insights of Reinhold Niebuhr, which King encountered at Crozer but studied more thoroughly at Boston University in the early 1950s, complicated his understanding of human nature, social relations, and Rauschenbusch's social gospel. According to Niebuhr, humankind could never achieve perfection in this world, given the persistence of evil and sin. Social relations, therefore, amounted to power relations, making moral suasion and progress ineffective without the use of force. The best hope and strategy for social activists, Niebuhr claimed, is the vigilant and always unstable management of society by means of coercive justice. "The limitations of the human mind and imagination, the inability of human beings to transcend their own interests sufficiently to envisage the interests of their fellowmen as clearly as they do their own 
makes force an inevitable part of the process of social cohesion," Niebuhr wrote. ${ }^{35}$

By the time he graduated from Crozer Theological Seminary, King had internalized many of Niebuhr's basic criticisms of liberal theology and its failure to account for the reality of evil, sin, and power. Early twentieth-century liberals, such as Rauschenbausch, had rewritten history as linear and morally progressive. According to King, they "believed that civilization was evolving toward an earthly paradise.... [They] became convinced that there is a sociological law of progress which is as valid as the physical law of gravitation." ${ }^{36}$ However, Niebuhr's insights into modern social evils had helped correct "the illusions of a superficial optimism concerning human nature" and induced King's recognition of "the complexity of man's social involvement and the glaring reality of collective evil.," ${ }^{\prime 37}$

Reevaluating Rauschenbusch, King wrote: "I felt that he had fallen victim to the nineteenth century 'cult of inevitable progress,' which led him to an unwarranted optimism concerning human nature." Prophetic moralizing on the ethic of love and brotherhood could not affect substantial social change or advance humanity toward the Kingdom of God without the leveraging of force. Social relations, for Rauschenbusch, were primarily moral relations, a view that Niebuhr and King ultimately qualified with the notion of power. According to King, Rauschenbusch also "came perilously close to identifying the Kingdom of God with a particular social and economic system." ${ }^{38}$ For King, that was sacrilegious. "As Christians we must never surrender our supreme loyalty to any time-bound custom or earth-bound idea, for at the heart of our universe is a higher realityGod and his kingdom of love-to which we must be conformed. ${ }^{\prime \prime 39}$ As these statements reveal, Niebuhr's lean toward neo-orthodoxy had convinced King of the transcendent sovereignty of God over any human, and thus flawed, designs.

Some historians, however, have overstated the extent to which King embraced Niebuhr's worldview. Chappell, to support his argument about the underlying pessimism of civil rights activists, claims that King accepted Niebuhr's cynical doctrine. ${ }^{40}$ Yet King's continuing faith in nonviolence indicates that he never gave up on his belief in humanity's essential goodness. As scholars Kenneth L. Smith and Ira G. Zepp cautioned, "King's testimony to Reinhold Niebuhr should not be interpreted to mean that he abandoned evangelical liberalism and accepted Niebuhrianism.. ${ }^{\prime 41}$ Luker also stated that "King... was never a thoroughgoing Niebuhrian." ${ }^{22}$ To understand how Christian realism helped to modify, but not abolish, the social gospel in King's theology, it is important to examine the reasons why 
King never became a converted Niebuhrian disciple. It is also necessary to evaluate Christian realism in terms of the social gospel. Max Stackhouse's claim that Niebuhr's Christian realism represented the second phase of the social gospel is complicated, but not groundless. Niebuhr, as a spokesperson for Christian realism, rejected the possibility of human or social perfectibility in this world, though he never advocated a disengagement from progressive social action. According to theologians Smith and Zepp, Niebuhr's call for a reconstructed liberal theology set him apart from continental theologians, such as the neo-orthodox Karl Barth. "Christian realism," Smith and Zepp argued, "was a more moderate reaction to liberalism than neoorthodoxy in that Christian realism retained a far greater concern for social ethics." ${ }^{\prime 3}$

Richard Wightman Fox, whose 1985 biography examines Niebuhr's disillusionment with the social gospel, provides support for the notion that Niebuhr's postliberal turn never developed into a complete revolution. Instead, the religious critic "had rigidly preserved the liberal conception of the self-the rational agency of goodwill-and the liberal idea of religion as a power for social transformation. ${ }^{\prime 44}$ Niebuhr offered $a$ social gospel, even as he derided the social gospel, in its classic, early twentieth-century form. Like earlier social gospelers, Niebuhr was still applying Christian ethics to socio-political problems after World War I. He insisted, however, on a more militant moral potency, arguing that liberals required a hefty dose of realism and humility in order to approximate ideals. They needed to acknowledge their limitations and jettison any self-righteous claims to moral purity. As Niebuhr concluded, justice, not pure agape love, represented the highest possible social goal, and justice called for the pragmatic use of coercion, even violence, when necessary. Searching for a realistic, if illiberal, means to bolster social change, Niebuhr quoted from the book of Matthew, exhorting Christians to "be wise as serpents and harmless as doves." ${ }^{15}$ In other words, altruistic activists should reformulate love and justice as effective levers of coercion against entrenched power. According to Fox, "Reinhold suggested that rather than leaving God to manage the brutalities of nature and society as He saw fit, men ought to intervene," even if the Kingdom of God on earth remained forever a futile fixation. ${ }^{46}$ By the 1930s, Niebuhr "no longer spoke of building the Kingdom of God." ${ }^{\prime 47}$ When he did speak of it, his tone was derisive.

King never went that far. He walked Niebuhr's middle path between idle fatalism and infinite humanism, concluding that "we must never feel that God will, through some breath-taking miracle or wave of the hand, cast evil out of the world.... The belief that God will do everything for man is as untenable as the belief that man can 
do everything for himself.," ${ }^{\prime 48}$ Nonetheless, King insisted that humans continue to take responsibility for their sins by acting as agents of God's will and the engine of divine teleology. God is "forever working through history for the establishment of His kingdom," he sermonized in $1957 .^{49}$

King appreciated Niebuhr's realism, but ultimately refuted the pessimism and defeatism underlying it. "I became so enamored of his social ethics that I almost fell into the trap of accepting uncritically everything he wrote," King admitted. ${ }^{50}$ The key word here is almost. The radical Baptist worried that neo-orthodoxy gave people an excuse to $\sin$ if they rationalized that it was irrevocably tied to their nature. In fact, King set neo-orthodoxy as the antithesis to liberalism and the social gospel. "An adequate understanding of man," he wrote, "is found neither in the thesis of liberalism nor in the antithesis of neoorthodoxy, but in a synthesis which reconciles the truths of both." ${ }^{151}$ Yet King's inconsistent use of the term "neo-orthodoxy" in relation to Niebuhr is problematic because it muddies the debate about whether he considered the Christian realist as part of the problem or part of the solution.

In the 1958 book Stride toward Freedom, King differentiated between Christian realism and continental forms of neo-orthodoxy by acknowledging that "Niebuhr's great contribution to contemporary theology is that he has refuted the false optimism characteristic of a great segment of Protestant liberalism without falling into the antirationalism of the continental theologian Karl Barth. ${ }^{\prime 52}$ However, King seemed to conflate Niebuhr and neo-orthodoxy by crediting them both with the "dimension of depth" in religion. "Neo-orthodoxy," he wrote, "certainly had the merit of calling us back to the depths of the Christian faith. ${ }^{\prime \prime 3}$ King attributed the same theological strength to Niebuhr in an unpublished memorandum, quoted by Smith and Zepp: "Reinhold Niebuhr, probably more than any other thinker in America, has stressed the need of a 'dimension of depth' transcending nature, transcending history, if ethical action here and now is to be sustained by a faith that touches absolute bottom. ${ }^{\prime 54}$ King also included Niebuhr in his critique of neo-orthodox cynicism toward human nature and moral progress. In Strength to Love, King deemed neo-orthodoxy "too pessimistic," the same characteristic he attributed to Niebuhr in a graduate school term paper he wrote on the Christian realist's ethical dualism. ${ }^{55}$ According to the Ph.D. candidate, Niebuhr ultimately failed "to deal adequately with the relative perfection which is the fruit of the Christian life. ${ }^{\prime 56}$ In other words, King wished to retain an optimistic faith in an approximated Kingdom of God rather than accept Niebuhr's dithering objections to it. Niebuhr asserted that "the dream of perpetual peace 
and brotherhood for human society is one which will never be fully realized. ${ }^{157}$ King, although chastened by Niebuhr's realism, refused to give up hope: "In a dark, confused world the Kingdom of God may yet reign in the hearts of men." 58

In short, King accepted a realistic adjustment to the social gospel, while retaining a faith in most of its central tenets, including moral progress toward the Kingdom of God. "Although I rejected some aspects of liberalism, I never came to an all-out acceptance of neo-orthodoxy," King explained. "While I saw neo-orthodoxy as a helpful corrective for a sentimental liberalism, I felt that it did not provide an adequate answer to basic questions." ${ }^{\text {" Th }}$ Those "basic questions" centered on how to combine realistically the wisdom of the serpent and the harmlessness of the dove without conceding, as King believed Niebuhr had done, to the inevitability of violence or the impossibility of social brotherhood. Before making his own revisions to Neibuhr's theories, King had almost "despaired of the power of love in solving social problems." ${ }^{160}$ However, his belief in the social gospel undergirded King's conviction that humans could overcome evil by learning to love and respect each other as equal children of the Father. He still needed a realistic method to advance Christian ideals. Rauschenbusch had recovered the central commandments of Christ, and Niebuhr had demanded a more practical approach to their implementation. As far as King was concerned, however, neither Rauschenbusch nor Niebuhr offered an adequate method to match their social message.

King finally found the means for a "realistic pacifism" in the civil disobedience of Third World freedom fighter Mahatma Gandhi. Scholars such as Smith and Zepp have expressed their concern that King's association with Gandhi threatens to undermine the essentially Christian aspects of his mission. ${ }^{61}$ Instead, King's use of Gandhi's methods reflected his determination to apply the social gospel to problems of power. Though he had studied Gandhi in college, King's appreciation for satyagraha solidified only after witnessing its effectiveness during the Montgomery bus boycott in the mid-1950s. During his first campaign for civil rights, King realized that Jesus' mandates from the Sermon on the Mount were actualized in nonviolent direct action. "This principle," he wrote, "became the guiding light of our movement. Christ furnished the spirit and motivation and Gandhi furnished the method." ${ }^{62}$ Gandhi, who drew upon Christian principles for his activism, transformed the love ethic into a lever of power, thus synthesizing idealistic means into a realistic weapon of social change. Through the praxis of satyagraha, King had discovered that "a third way is open to our quest for freedom, namely, nonviolent 
resistance, that combines toughmindedness and tenderheartedness and avoids the complacency and do-nothingness of the softminded and the violence and bitterness of the hardhearted." ${ }^{63}$ As King explained in the essay "Pilgrimage to Nonviolence," "many of the things that I had not cleared up intellectually concerning nonviolence were now solved in the sphere of practical action." ${ }^{\prime 4}$

By taking direct action in the form of peaceful protest, King and his fellow civil rights activists exerted powerful economic, political, and moral leverage against Jim Crow oppression. A year-long struggle against the Montgomery bus system had demonstrated the effectiveness of the boycott in economic and political terms. Yet King remained unsatisfied with these short-term and relatively superficial concessions from the persistently racist white community. He hoped for a more radical change that would permeate the whole culture, a revolution in values that could transform neighborhoods into brotherhoods. Given these objectives, King put his faith in the moral power of nonviolent campaigns for justice to stir the complacent hearts and minds of Americans and provoke them to realign their religious beliefs around ethical practice.

The idea was that southern blacks, blameless but suffering in a system of social sinfulness, would invoke shame and vicarious suffering within whites who would begin to recognize the peaceful, innocent victims of injustice as children of God and members of the human family. As King wrote in 1962, the "dark and demonic" roots of evil behavior "will be removed only as men are possessed by the invisible, inner law which etches on their hearts the conviction that all men are brothers and that love is mankind's most potent weapon for personal and social transformation." ${ }^{65}$ Nonviolent resistance as an expression of love rather than reciprocal hate, King insisted, contained this power to reconcile former enemies and recreate community in a way that violent action never could.

The cultural power of peaceful protest helped King resolve his intellectual perplexity about Niebuhr's critical assessment of pacifism, which, King admitted, "left me in a state of confusion." The "shortcomings of [Niehbuhr's] position" amounted to a "serious distortion" of nonviolent resistance to connote passive nonresistance. The two terms, King insisted, carried singularly distinct conceptual meanings. "True pacifism," King asserted, "is not unrealistic submission to evil power, as Niebuhr contends. It is rather a courageous confrontation of evil by the power of love." ${ }^{\prime 66}$ To be fair, King failed to dissect the complexities of Niebuhr's reasoning. Niebuhr was not labeling Gandhian tactics as passive. He was arguing that nonviolent resistance was actually more coercive than its practitioners were willing to admit. 
"The responsible leader of a political community is forced to use coercion to gain his ends," Niebuhr wrote. "He may, as Mr. Gandhi, make every effort to keep his instrument under the dominion of his spiritual ideal; but he must use it, and it may be necessary at times to sacrifice a degree of moral purity for political effectiveness. ${ }^{\prime 67}$ Nonviolent resistance or "nonviolent coercion," Niebuhr believed, offered the best strategy for leveraging power and maintaining the rational, moral high ground over one's opponents. Niebuhr even expressed his hope that Gandhian methods of nonviolence could be imported to the United States and applied to the issue of civil rights. "The emancipation of the Negro race in America," he prophetically surmised, "probably waits upon the adequate development of this kind of social and political strategy. ${ }^{\prime 68}$

If King misunderstood Niebuhr in part, he correctly detected the troubling upshot of Moral Man and Immoral Society: The difference between violence and nonviolence was a matter of degree. Moreover, nonviolent resistance was an act of justice, not love, according to Niebuhr. The former implied force, while the latter implied suasion. Niebuhr, in certain passages of Moral Man and Immoral Society, even stripped Jesus of his social gospel: "[Jesus] did not say that the enemy ought to be loved so that he would cease to be an enemy. He did not dwell upon the social consequences of these moral actions, because he viewed them from an inner and transcendent perspective. ${ }^{\prime 69}$ King rejected such conclusions in favor of his own theory about the creative power of agape love. "Love even for enemies is the key to the solution of the problems of our world," he asserted. "Jesus is not an impractical idealist: he is the practical realist." ${ }^{\prime 70}$ Love and nonviolence, for King, were the only acceptable means concurrent with the ends of building beloved communities prefiguring the Kingdom of God.

Matching means and ends, according to King, was crucial for creating thorough going cultural and social change, a radical move beyond the mere mechanical rearrangement of power in society. "The problem never will be solved by substituting one tyranny for another. Black supremacy is as dangerous as white supremacy," King warned. Civil rights activists, in other words, were fighting for freedom and a balance of power, not the usurpation of power or vengeance against whites. Violent means would reinforce a violent, divided world, but King wanted an integrated society in which "all men can live together as brothers, where every man will respect the dignity and the worth of human personality." 71 For the social gospel to permeate all social relations, though, activists needed to commit themselves to the ongoing cultural project of changing behavior and attitudes, a revolution of values that coercive legislation could never achieve on its own. 
King's emphasis on respecting "the dignity and worth of human personality" was an expression of his belief in personalism, a theological concept that posits personality, both infinite (God) and finite (humans), as the ultimate reality. King considered personalism his "basic philosophical position." 72 If God is personality, and humans are children of God, then the reality of God is expressed through human personality. Consequently, King avowed that to deny a person his freedom "is to rob him of something of God's image." Social injustice also undermined the Kingdom of God on earth. As King concluded, "The Kingdom of God is neither the thesis of individual enterprise nor the antithesis of collective enterprise, but a synthesis which reconciles both. ${ }^{\prime 74}$ This synthesis of personal and social development linked individual destiny to that of collective integration. King also referred to it as creating the beloved community.

Defining community as "the mutually cooperative and voluntary venture of man to assume a semblance of responsibility for his brother," King envisioned small, local fellowships in which the "persistent exercise" of civil and human rights would become normative practice, "usual and ordinary in human contact." ${ }^{\text {75 }}$ He did not believe such a transformation was possible, however, without adherence to the basic precepts of the social gospel. Jesus had commanded his followers to love one another, care for one another, feed the hungry, heal the sick, and comfort the afflicted. King expected neighbors to foster such Christian action in their own communities, even if it seemed unfeasible or fanatic. "Our goal is to create a beloved community," he wrote in Ebony magazine in 1966, "and this will require a qualitative change in our souls as well as a quantitative change in our lives." ${ }^{.76}$ If the Kingdom of God had any hope in this world, it existed, according to King, in the potential for people to cultivate the goodness within themselves, wherever they lived.

Getting to the "promised land" or building the "beloved community" from the bottom up was not inevitable, King made clear, but it was possible through human endeavors to promote peace, love, and cooperation. Here, he was stretching the social gospel to its most radical implications - the creation of the beloved community in the here and now, in the complete restructuring of society and human relations. In their book on King's conception of the beloved community, Smith and Zepp argued that with his "advocacy of nonviolent sabotage" King took a radical turn beyond liberalism. ${ }^{77}$ Rauschenbusch biographer Christopher $\mathrm{H}$. Evans agreed: "To be sure, the next generation of social gospelers addressed, sometimes boldly, a range of social issues... related to racial justice and gender equality that went beyond the Victorian suppositions of the original social gospel 
movement." ${ }^{783}$ King's father and grandfather had preached a social gospel of black liberation at Ebenezer Church in Atlanta for decades. However, King went beyond the reform-minded measures of his elders. ${ }^{79}$ He sought instead to redirect and revitalize social gospel principles for the needs of those fighting against mid-twentiethcentury oppression, whether social, political, or economic. In short, he considered the social gospel, put into practice, as a decentralized, spiritualized form of socialism.

While at Crozer, King revealed that his pursuit of social and economic justice stemmed directly from his social gospel values. "I must be concerned about unemployment, slums, and economic insecurity," he said. "I am a profound advocator of the social gospel." 80 The prevalence of poverty throughout the nation, King asserted, meant that Christ's commands to love and care for one another as a family had gone unheeded. Instead of cultivating a Christian culture in their communities, Americans had opted for the wealth and material comfort of capitalism, a system of economic inequality, self-interest, and oppression that King considered antithetical to true Christian discipleship. In his version of socialism, everyone would have equal access to employment, political participation, education, decent housing, and health care. He did not assign special privilege to any single class or race, but believed that every individual had equal value as an extension of God. Cultural prejudice prevented people from recognizing each other as brothers and sisters in Christ, as King had always stated. However, institutional structures, which he increasingly criticized, also acted as barriers to change, convincing people that the prevailing order existed as fixed and natural. As early as 1960 , King made the connection by saying that a revolution was necessary to affect "both the social order and the human mind." Seven years later, he declared that "a true revolution of values will soon look uneasily on the glaring contrast of poverty and wealth ... to see that an edifice which produces beggars needs restructuring." ${ }^{\prime 81}$

These structures of oppression, King realized, weighed upon people, especially people of color, all over the world. His method for global revolution, however, remained the same as his method for local and national change - the application of social gospel values to build a beloved community across racial, cultural, and geographic borders. "Through our scientific genius we have made of this world a neighborhood; now through our moral and spiritual development we must make of it a brotherhood," he exhorted. ${ }^{82}$

This brings us to Stackhouse's fourth and final phase of the social gospel, liberation theology, a mid-twentieth-century movement in which the oppressed became "agents of their own destiny" by 
applying Christ's social mandates to the conditions and experiences of the postcolonial poor in Latin America, Africa, and Asia. Calling for a "total gospel in all its radicalness," liberation theologians such as Gustavo Gutierrez insisted that the poverty, exploitation, and neglect of millions of people around the world stood "contrary to the will of the God of Christian revelation" through Jesus Christ. ${ }^{83}$ Social injustice was attributed to the prevalence of sin, which blocked communication and reconciliation with God and fellow human beings. To redeem the world of its sin, liberation theologians posited a "preferential option of the poor" or solidarity with the poor as the most authentic expression of universal Christian love and Christian praxis of God's will in historical time. As Gutierrez wrote:

If we believe that the Kingdom of God is a gift which is received in history, and if we believe, as the eschatological promises-so charged with human and historical content indicate to us, that the Kingdom of God necessarily implies the reestablishment of justice in this world, then we must believe that Christ says that the poor are blessed because the Kingdom of God has begun. ${ }^{84}$

King's radical social gospel grafted seamlessly onto the substance of liberation theology with its emphasis on postmillennial, social salvation and the needs of the poor. Here he found an organic expression of primitive Christianity and the social gospel among men and women who may not have ever heard of Walter Rauschenbusch or Reinhold Niebuhr. What's more, in this version of the social gospel, the oppressed themselves, not white, middle-class reformers, were empowered as moral agents of change. Theologian Trimiew, insisting that the classic social gospel was fundamentally characterized by racial exclusivity, argued that King must be recognized, not as a disciple of the classic social gospel tradition, but as an exponent of a "new social gospel," distinguished by its multiethnic mission of racial liberation. While Trimiew overstated his case for the "inherent racism of the social gospel," his insight into King's broader vision is useful for understanding King's connection to postcolonial liberation theologians. ${ }^{85}$

Liberation theologians accepted the accompaniment of all Christians, while emphasizing the empowerment of the poor themselves. Gutierrez, for example, was careful to correct mistaken assumptions that liberation theology originated with the middle class. He reminded readers that "during the 1950's and 60's we saw the first steps being taken in conscientization, and we saw the poor beginning to organize themselves in defense of their right to life, in the struggle for dignity and social justice, and in a commitment to their own 
liberation." ${ }^{\prime 86}$ Gutierrez also warned against paternalism from wellintentioned Christians who struggled on behalf of, instead of alongside, the poor. "Sensitivity to these and other dangers is part of a human and Christian praxis whose truly liberating effects extend to those also who are trying to carry on such a praxis for the benefit of the poor and exploited," he wrote. "If there is no friendship with them and no sharing of the life of the poor, then there is no authentic commitment to liberation, because love exists only among equals." ${ }^{\prime 87}$

King, drawing upon his own experiences in the civil rights movement, understood Guterriez's problem. Well-intentioned white activists "tended, in some instances, to be rather aggressive and insensitive to the opinions and abilities of the black people with whom they were working," King wrote. Inevitably, he explained, blacks began to resent the condescending attitudes of their white co-activists and thus "moved to assert their own equality and to cast off the mantle of paternalism." ${ }^{88}$ King sought to avoid this problem in the campaign for global solidarity and liberation. "Instead of seeking to do something with the African and Asian peoples, we have too often sought only to do something for them," he lamented. ${ }^{89}$

King regarded the struggle for black human rights in America as part of the global movements for postcolonial liberation. "This determination of Negro Americans to win freedom from all forms of oppression springs from the same deep longing that motivates oppressed people all over the world," he declared. "The rumblings of discontent in Asia and Africa are expressions of a quest for freedom and human dignity by people who have long been the victims of colonialism and imperialism." ${ }^{\prime 90}$ In "A Testament of Hope," he envisaged a special role for African Americans in international relations: "I have come to hope that American Negroes can be a bridge between white civilization and the nonwhite regions of the world, because we have roots in both." ${ }^{\prime 91}$ African Americans, as both subjects and objects of the American empire, offered a unique perspective on the issue of imperialism. Therefore, they were perfect mediators for global conflict resolutions. King's trips to India and Ghana reinforced his belief that the racially and economically oppressed in America, Asia, Africa, and Latin America shared a common experience. White activists committed to social justice often struggled in solidarity with the poor and exploited. Certainly, their participation was crucial for building the bonds of global brotherhood. "But the strongest bond of fraternity," King observed, "was the common cause of minority and colonial peoples in America, Africa, and Asia struggling to throw off racism and imperialism.".92

King repeatedly emphasized the universality of his religious message as a struggle for the liberation of all nations and peoples, not 
just black Americans. He also made it clear that his faith in the ability of racial minorities and black religions around the world to redeem humanity was contingent upon their devotion to social gospel values, including nonviolence in both means and ends. ${ }^{93}$ Drawing upon the examples of Gandhi in India and Kwame Nkrumah in Ghana, King insisted that the end of a colonial relationship did not necessitate the end of international cooperation. In each case, the nonviolent campaigns for independence had not permanently caused a breach between the imperial power and the former colony. Instead, the paths of communication and reconciliation had remained open. As King wrote, "The way of violence leads to bitterness in the survivors and brutality in the destroyers. But the way of nonviolence leads to redemption and the creation of the beloved community. I returned to America with a greater determination to achieve freedom for my people through nonviolent means." ${ }^{94}$ Convinced of the interdependence of all people, King did not believe that the Kingdom of God could emerge anywhere unless peaceful activists cultivated it everywhere.

King's social gospel theology and praxis, then, contained universal implications that transcended the special dispensation of any single group or race of people. As such, it also transcended the political exceptionality of the United States and the American dream. At times, King insisted that his global vision of peace, equality, and brotherhood was "deeply rooted in the American Dream" of life, liberty, and the pursuit of happiness. ${ }^{95}$ However, he realized that the ideals expressed in the Declaration of Independence and the U.S. Constitution represented mere intentions, not actualities. Americans, who tacitly accepted racism and economic exploitation, had yet to make the leap from democratic rhetoric to democratic reality. Democracy needed to undergo a transformation "from thin paper to thick action" in order to fulfill the promises of its rhetoric. Dedicated to the Southern Christian Leadership Conference motto "To Save the Soul of America," King believed that black Americans, through their unearned suffering and incessant strivings for justice, represented a vanguard for American redemption. "In these trying circumstances," King wrote in the vein of prophetic religion, "the black revolution is much more than a struggle for the rights of Negroes. It is forcing America to face all its interrelated flaws-racism, poverty, militarism and materialism." 96

According to Singh, "King argued that the U.S. nation-state was neither a stable mediator of social antagonisms nor the ultimate horizon of black hopes for justice." ${ }^{\prime 97}$ Singh is certainly correct, but he does not take the point far enough. King ultimately pushed past the 
U.S. nation-state and the needs of the black community to prophesize redemption for all of God's creation. "One of the great tragedies of man's long trek along the highway of history has been the limiting of neighbourly concern to tribe, race, class, or nation," King wrote in Strength to Love. ${ }^{98}$ Based as it was in universal truths, the campaign for civil and human rights in America, he maintained, carried transnational implications for liberation movements throughout the world. "Our present suffering and our nonviolent struggle to be free may well offer to Western civilization the kind of spiritual dynamic so desperately needed for survival," he wrote. ${ }^{99}$ Here again, King placed social gospel values, not American political principles, at the forefront of revolution. King hoped that the practice of the social gospel, exemplified by liberation theology, would preempt the tendency among white, middle-class social missioners to assume a posture of cultural and political superiority.

Christian activists, King believed, needed to emulate the actions of the Good Samaritan on Jericho Road. Though the Good Samaritan was "a man of another race," he "got down from his beast, decided not to be compassionate by proxy," and, instead, administered aid from a position of equality at the side of the man in need. "Jesus ended up saying this was the good man," King concluded, "because he had the capacity to project the ' $I$ ' into the 'thou,' and to be concerned about his brother." ${ }^{100}$ The Good Samaritan's concern was expressed in true solidarity and compassion, not paternalistic charity. This particular point, popular among liberation theologians, was known as accompaniment, the responsibility of one human being to struggle alongside another in times of trouble, as equals. ${ }^{101} \mathrm{King}$ considered it as the only way to build the Kingdom of God and the brotherhood of man on earth.

The honor of the Nobel Peace Prize in 1964 strengthened King's resolve to "work harder than I had ever worked before for the brotherhood of man. This is a calling that takes me beyond national allegiances." ${ }^{102}$ His insistence that an injury to the dignity of any person represented an insult to God undergirded his vision of a modern social gospel for an era of rapid globalization-a social gospel that transcended barriers of race, class, and nation. Historians White and Hopkins put it best when they wrote: "The Kingdom of God was not simply the American Dream." ${ }^{103}$ It was not simply a matter of moral suasion either. King recognized the need to marshal forces of moral power and apply moral leverage to achieve justice. Despite the persistence of sin, however, King continued to believe that through personalism and the gift of the gospels humans had access to the will of God and, thus, the ability to choose transnational brotherhood over 
national interests. He appealed to this innate sense of person-toperson compassion when he addressed issues of civil rights and the Vietnam War. "I think most Americans know in their hearts that their country has been terribly wrong in its dealings with other peoples around the world," he wrote in reference to the war in Vietnam. ${ }^{104}$

By 1967, King was ready to speak out, openly and unequivocally, against inhumane U.S. policies in Southeast Asia: "We must stop now. I speak as a child of God and brother to the suffering poor of Vietnam. ... I speak as a citizen of the world." ${ }^{105}$ While many scholars have interpreted King's antiwar stance as a decided break from his earlier focus on civil rights, it is actually an organic extension of his religious worldview. As Singh stated, "King refused to see his antiwar stance ... as inconsistent with his earlier views." ${ }^{106}$ Yet Singh, by threading the continuity of King's thought through the concept of the long civil rights movement instead of the long social gospel movement, marginalized King's Kingdom ethics. Racial justice, for King, derived from God's will for an all-encompassing social justice. As he wrote in Strength to Love:

Christians are also bound to recognize the ideal of a world unity in which all barriers of caste and colour are abolished. Christianity repudiates racism. The broad universalism standing at the centre of the gospel makes both the theory and practice of racial injustice morally unjustifiable. Racial prejudice is a blatant denial of the unity which we have in Christ, for in Christ there is neither Jew nor Gentile, bond nor free, Negro nor white. ${ }^{107}$

King modified his conception of the classic social gospel with a dose of Christian realism and, thus, expanded the social message of Christ to its broadest, most inclusive, most radical extensions. He never abandoned a fundamental faith in nonviolent social action, the power of love, human solidarity, or the historically revealed Kingdom of God. At the time of his death in 1968, despite all the trials and tribulations he had endured, King remained a steadfast proponent of a radical social gospel for the world. By placing King in the stream of the long social gospel movement, we can discuss his radicalism within a religious context. Douglas Sturm came close when he claimed that "King's democratic socialism was not Marxist in the classical or orthodox sense of that movement; it was instead a democratic socialism derived through the social gospel of Rauschenbusch, modified by the Christian realism of Niebuhr, and governed by the basic philosophical categories of personalist idealism." ${ }^{108}$ However, Sturm did not recognize the continuity of these ideas within the long 
social gospel tradition, an insight that makes King's religious radicalism easier to trace from stem to stern.

By analyzing King's social gospel ethos, we can also cut King out of the controversies surrounding the long civil rights movement, particularly the debates over time and timelessness. ${ }^{109}$ King applied universal Christian values to the problems of his day, which prevents him from being "frozen in 1963," as Singh and Dowd Hall feared liberals and conservatives had decreed. King constantly used the social gospel as a touchstone for the moral dilemmas he faced as a popular political figure throughout the 1950 s and $1960 \mathrm{~s}$. His application of universal values makes him both a benchmark figure within a continuous radical tradition and an historical agent working within the unique contingencies of a particular time and place.

\section{Notes}

1. Martin Luther King, Jr., "Beyond Vietnam," in The Autobiography of Martin Luther King, Jr., ed. Clayborne Carson (New York: Warner Books, 1998), 336.

2. Douglas Sturm, "Martin Luther King, Jr., as Democratic Socialist," Journal of Religious Ethics 18 (Fall 1990): 79-105. Nikhil Pal Singh, Black Is a Country: Race and the Unfinished Struggle for Democracy (Cambridge: Harvard University Press, 2004).

3. Singh, Black is a Country, 2.

4. Jacqueline Dowd Hall, "The Long Civil Rights Movement and the Political Uses of the Past," Journal of American History (March 2005): 1234.

5. Lew is V. Baldwin, There Is a Balm in Gilead: The Cultural Roots of Martin Luther King, Jr. (Minneapolis: Fortress Press, 1991), 2. For more on King and the black church, see also James H. Cone, "Martin Luther King, Jr.: Black Theology-Black Church," Theology Today 40 (January 1984): 409-12.

6. Martin Luther King, Jr., Stride toward Freedom: The Montgomery Story (New York: Harper \& Brothers, 1958), 91.

7. See Clayborne Carson, "Martin Luther King, Jr., and the African-American Social Gospel," in African-American Christianity: Essays in History, ed. Paul E. Johnson (Berkeley: University of California Press, 1994), 159-78. Carson challenges scholars such as Baldwin and Cone for producing a false dichotomy between King's African American religious experience and his academic study of white European theologians and American social gospel thinkers. 
8. Baldwin acknowledges as much when he writes that "King... spoke of the necessity for the Negro church to remain true to its Social Gospel tradition ... and that practical applications of Social Gospel principles had never required a retreat from black-church orthodoxy." In this statement, Baldwin shows that scholars can recognize the centrality of the social gospel to King as a standard of ethics without marginalizing his relationship to the black church. See Lewis V. Baldwin, The Voice of Conscience: The Church in the Mind of Martin Luther King, Jr. (Oxford: Oxford University Press, 2010), 140.

9. David L. Chappell, A Stone of Hope: Prophetic Religion and the Death of Jim Crow (Chapel Hill: University of North Carolina Press, 2004).

10. Michael K. Honey, Going Down Jericho Road: The Memphis Strike, Martin Luther King's Last Campaign (New York: W.W. Norton, 2007).

11. Martin Luther King, Jr., A Testament of Hope, 234.

12. Ibid. 232.

13. King, Jr., Autobiography, 337.

14. Ibid.

15. C. Howard Hopkins, The Rise of the Social Gospel in American Protestantism, 1865-1915 (New Haven: Yale University Press, 1940); Robert T. Handy, ed., The Social Gospel in America, 1870-1920 (New York: Oxford University Press, 1966).

16. Christopher Lasch, "Religious Contributions to Social Movements: Walter Rauschenbusch, the Social Gospel, and Its Critics," Journal of Religious Ethics 18 (Spring 1990): 7-25.

17. Ralph E. Luker, The Social Gospel in Black and White: American Racial Reform, 1885-1912 (Chapel Hill: University of North Carolina Press, 1991); Susan Hill Lindley, "Deciding Who Counts: Toward a Revised Definition of the Social Gospel," and Darryl M. Trimiew, "The Social Gospel Movement and the Question of Race," in The Social Gospel Today, ed. Christopher H. Evans (Louisville: Westminster John Knox Press, 2001), 17-37.

18. Christopher H. Evans, "Introduction: Historical Integrity and Theological Recovery," in Evans, The Social Gospel Today, 1-13.

19. Ronald C. White, Jr., and C. Howard Hopkins, The Social Gospel: Religion and Reform in Changing America (Philadelphia: Temple University Press, 1976), xi, 244. 
20. Max L. Stackhouse, "The Fifth Social Gospel and the Global Mission of the Church," in Evans, The Social Gospel Today, 146-51.

21. Sturm, "Martin Luther King Jr. as Democratic Socialist," 84.

22. Kenneth L. Smith and Ira G. Zepp, Jr., Search for the Beloved Community: The Thinking of Martin Luther King, Jr. (Valley Forge: Judson Press, 1974), 26-41.

23. Chappell, A Stone of Hope, 45.

24. Martin Luther King, Jr., and Thich Nhat Hanh, "A Joint Statement," of the International Committee of Conscience on Vietnam, quoted in Baldwin, The Voice of Conscience, 212.

25. King, Jr., Stride toward Freedom, 90.

26. Ibid., 91.

27. Ibid.

28. Walter Rauschenbusch, Christianity and the Social Crisis (1907; reprint, New York: HarperCollins, 2007), 6, 8.

29. Ibid., 50 .

30. King, Jr., Stride toward Freedom, 91.

31. Martin Luther King, Jr., Strength to Love (Philadelphia: Fortress Press, 1963), 150.

32. Ibid., 100.

33. King, Jr., Autobiography, 19.

34. King, Jr., Strength to Love, 148.

35. Reinhold Niebuhr, Moral Man and Immoral Society: a Study in Ethics and Politics (New York: Scribner's Sons, 1932; reprint, New York: Scribner's Sons, 1960), 6.

36. Ibid, 72 .

37. King, Jr., Stride Toward Freedom, 99. Hope, 37.

38. King, Jr., "Pilgrimage to Nonviolence," in A Testament of

39. Ibid, 18.

40. Chappell, A Stone of Hope, 48-54.

41. Smith and Zepp Jr., Search for the Beloved Community, 71. 
42. Ralph E. Luker, "The Kingdom of God and Beloved Community in the Thought of Martin Luther King, Jr.," in The Role of Ideas in the Civil Rights South, ed. Ted Ownby (University Press of Mississippi, 2002), 50.

43. Ibid., 73.

44. Richard Wightman Fox, Reinhold Niebuhr: A Biography (Ithaca: Cornell University Press, 1985), 145.

45. Reinhold Niebuhr, Children of Light, Children of Darkness: A Vindication of Democracy and a Critique of Its Traditional Defense (New York: Scribner's Sons, 1947).

46. Ibid., 133.

47. lbid., 140.

48. King, Jr., Strength to Love, 133.

49. Martin Luther King, Jr., "Give Us the Ballot," in A Call to Conscience: The Landmark Speeches of Dr. Martin Luther King, Jr., ed. Clayborne Carson and Kris Shepard (New York: Grand Central Publishing, 2001), 54 .

50. King, Jr., Stride toward Freedom, 97.

51. King, Jr., Strength to Love, 149.

52. King, Jr., Stride toward Freedom, 99.

53. King, Jr., Autobiography, 31.

54. Smith and Zepp, Jr., Search for the Beloved Community, 31. Note the social gospel language in the phrase "if ethical action here and now is to be sustained."

55. King, Jr., Strength to Love, 148.

56. Martin Luther King, Jr., "Reinhold Niebuhr's Ethical Dualism," quoted in Smith and Zepp, Jr., Search for Beloved Community, 81.

57. Niebuhr, Moral Man and Immoral Society.

58. King, Jr., Strength to Love, 155.

59. Ibid., 148.

60. King, Jr., Stride toward Freedom, 95.

61. Smith and Zepp, Jr., Search for the Beloved Community, 2.

62. Ibid., 151. 
63. Ibid., 15.

64. King, Jr., Stride toward Freedom, 101. The essay "Pilgrimage to Nonviolence," like many of King's works, is printed with only minor revisions in several compilations, including Strength to Love and the Autobiography.

65. Martin Luther King, Jr., "The Ethical Demands for Integration," in A Testament of Hope, 124. For more on King's conception of redemptive suffering, see "Love, Law, and Civil Disobedience," in A Testament of Hope, 47.

66. King, Jr., Stride toward Freedom, 98.

67. Niebuhr, Moral Man and Immoral Society, 244.

68. Ibid., 252.

69. Tbid., 264.

70. King, Jr., Strength to Love, 48.

71. Martin Luther King, Jr., "The American Dream," in A Testament of Hope, 215.

72. King, Jr., Stride toward Freedom, 100.

73. Martin Luter King, Jr., "The Birth of a New Nation," in A Call to Conscience, 20.

74. King, Jr., Stride toward Freedom, 95.

75. Martin Luther King, Jr., "The Ethical Demands for Integration," and "An Address before the National Press Club," in A Testament of Hope, 122, 102.

76. Martin Luther King, Jr., "Nonviolence: The Only Road to Freedom," in A Testament of Hope, 58.

77. Smith and Zepp, Jr., Search for the Beloved Community, 137.

78. Christopher H. Evans, The Kingdom Is Always but Coming: A Life of Walter Rauschenbusch (Grand Rapids: William B. Eerdmans Publishing Co., 2004), 318.

79. For more on King, Jr.'s radical move beyond his father, see Baldwin, The Voice of Conscience, 47.

80. Quoted in ibid., 63.

81. Martin Luther King, Jr., "The Burning Truth in the South," and "A Time to Break Silence," in A Testament of Hope, 98, 241. 
82. King, Jr., "The American Dream," 209.

83. Gustavo Gutierrez, A Theology of Liberation: History, Politics, and Salvation (1973; reprint, New York: Orbis Books, 1988), xxii.

84. Ibid., 171.

85. Trimiew, "The Social Gospel Movement and the Question of Race," 33-37.

86. Gutierrez, A Theology of Liberation, xxix.

87. Ibid., xxx-xxxi.

88. Martin Luther King, Jr., "A Testament of Hope," in A Testament of Hope, 316.

89. King, Jr., Strength to Love, 32.

90. King, Jr., Autobiography, 107.

91. King, Jr., "A Testament of Hope," 318.

92. King, Jr., Autobiography, 123.

93. See Baldwin, The Voice of Conscience, 206-7.

94. King, Jr., Autobiography, 134.

95. Martin Luther King, Jr., "I Have a Dream," in A Call to Conscience, 85 .

96. King, Jr., “A Testament of Hope," 315.

97. Singh, Black Is a Country, 14.

98. King, Jr., Strength to Love, 28.

99. Ibid., 92.

100. Martin Luther King, Jr., "I've Been to the Mountaintop," in A Call to Conscience, 217-18.

101. For a history of the concept of accompaniment in liberation theology, including the civil rights movement in the United States, see Staughton Lynd, Accompanying: Pathways to Social Changc (Oakland: PM Press, 2012).

102. King, Jr., "Beyond Vietnam," in A Call to Conscience, 145.

103. White and Hopkins, The Social Gospel, xix.

104. King, Jr., “A Testament of Hope,” 323. 
105. King, Jr., "Beyond Vietnam," 153.

106. Singh, Black Is a Country, 2 .

107. King, Jr., Strength to Love, 101.

108. Sturm, "Martin Luther King Jr. as Democratic Socialist," 91.

109. Sundiata Keita Cha-Jua and Clarence Lang, "The 'Long Movement' as Vampire: Temporal and Spatial Fallacies in Recent Black Freedom Studies," Journal of African American History 92 (Spring 2007): 265-88.

A BSTRACT Historians have posited several theories in an attempt to explain what many regard as Martin Luther King, Jr.'s radical departure, in the late 1960 's, from his earlier, liberal framing of civil rights reform. Rather than view his increasingly critical statements against the Vietnam War and the liberal establishment as evidence of a fundamental change in his thinking, a number of scholars have braided the continuity of King's thought within frameworks of democratic socialism and the long civil rights movement, respectively. King's lifelong struggle for racial justice in America, they argue, was rife with broader and more radical implications than that of a national campaign for political inclusion. His message was global, and it was revolutionary. However, when depicting him exclusively in the context of black radicals during "the long civil rights movement," or the labor movement, these scholars have a tendency to downplay the most fundamental component of King's activism - his religion. More so than he referenced the brave black leaders of previous civil rights campaigns, King drew upon the writings and ideas of social gospel thinkers, such as Walter Rauschenbusch and Reinhold Niebuhr. By analyzing King within the context of "the long social gospel movement" in addition to "the long civil rights movement," we can explain his radical social mission in terms of race and class, but without marginalizing the Christian values at the core of his calling.

Keywords: Martin Luther King, Jr., Social gospel, long social gospel movement, long civil rights movement, Christian realism, Liberation theology 